\title{
プラズマ・アンジュレーター
}

鈴木康夫

(日本原子力妍究所 東海研究所)

(1992 年 5 月 20 日受理 1992 年 8 月 10 日改訂原稿受理)

\section{Plasma Undulator}

Yasuo Suzuki

(Received May 20, 1992/Revised Manuscript Received August 10, 1992)

\begin{abstract}
Two types of the undulator which is developed as a generator of the highly brilliant light for the synchrotron radiation sources and the free electron lasers, are newly proposed using the array of slender plasmas columns. One is the magnetic field type, in which the undulator force on the relativistic electron beam is generated with the electric current flowing through the plasma columns. The other is the electric field type, in which the undulator force is generated with the periodic variation of the density between the slender plasma columns. The production methods and the stabilization ones of plasma columns are discussed.
\end{abstract}

Keywords:

synchrotron radiation, undulator, plasma, free electron laser, synchrotron radiation source,

\section{1. はじめに}

プラズマの新しい応用の一つとして，プラズマ・アンジュレーターを提案する．最近，プラズマの 応用分野として, 半導体や超電導材料など新しい材料の創製や, 新しい原理に基づく加速器の開発に プラズマ技術が考えられているが，ここでは，放射光や自由電子レーザーに用いられる光源用のアン ジュレーターへの応用の一例を報告する。

アンジュレーターとは, 相対論的電子ビームを蛇行（アンジュレーション運動）させて，その際に 生ずるシンクロトロン放射光を発生させる装置である. 蛇行させるためには, 進行方向之直交する方 向に周期的に力を加える必要があり，一般的には，周期的に配列された永久磁石を用いて作る. アン ジュレーターは, 第 3 世代放射光施設（たとえば，西播磿に建設されている SP ring-8) や自由電子レー ザーの相対論的電子ビームの運動エネルギーを X 線や赤外線の光に換える主要な装置となっている.

Tokai Research Establishment, Japan Atomic Energy Research Institute, Ibaraki 319-11. 


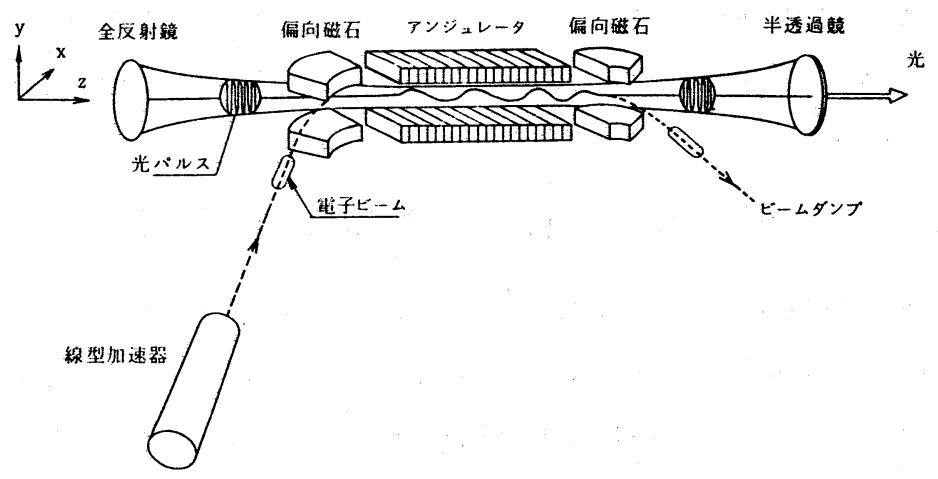

第 1 図 自由電子レーザーの原理 線型加速器から出た相対論的電子ビームは，ア ンジュレーターという周放射光を発する. この光は鏡 2 枚で構成される光共振器により，続いて 入射してくる電子ビームと相互作用し，光を増幅する.

自由電子レーザーでのアンジュレーターの利用法を第 1 図に示す。この図では, $\mathrm{z}$ 軸方向に沿って $\mathrm{y}$ 方向に周期的な磁場（正弦波状）を作っている．この磁場によって蛇行する電子ビームからは，いわ ゆるシンクロトロン放射光（アンジュレーター放射光）が放出される. その光は, 同一軸上での多数 回の発光が干渉により強めあい，準単色の光となる， $\mathrm{n}$ 次の高調波の波長は，

$$
\lambda_{\mathrm{n}}=\frac{\lambda_{\mathrm{u}}}{2 n \gamma^{2}}\left(1+\frac{K^{2}}{2}\right)
$$

で表される ${ }^{\mathrm{r}}$.ここで, $\lambda_{\mathrm{u}}$ はアンジュレーター磁場の波長 (周期長)， $\gamma$ はいわゆるローレンッ・ファ クター $\gamma=\sqrt{1-(v / c)^{2-1}}=E / m_{0} c^{2}=1957 E[\mathrm{GeV}](E$ は電子ビームのエネルギー) である.

$K$ はアンジュレーターの性質を特徵づけるパラメータで,

$$
K=\frac{e B_{0} \lambda_{\mathrm{u}}}{2 \pi m_{0} c}=93.4 \quad \lambda_{\mathrm{u}}[\mathrm{m}] \quad B_{0}[\mathrm{~T}]
$$

ここで, $B_{0}$ はアンジュレーター磁場の振幅であり， $m_{0}$ は電子の静止質量である.

$K \leq 1$ の時をアンジュレーターといい，この場合は周期数だけの発光が重なり，その間に干渉が起 き指向性が強く，幅の狭いスペクトルとなる，K》1の時はウイグラーといい，幅広いスペクトル光 が発生する.

発生したアンジュレーター放射光を光共振器に入れ, 蛇行電子パルスと共振させれば増幅が可能と なり，いわゆる誘導放射となる。

さて，著者の関心は，いかに経済的に短波長の光源を作るかにある（1）式からわかるように，発 生する光の波長は, アンジュレーターの周期長に比例し，相対論的電子ビームのエネルギーの 2 乗に 反比例する．電子ビームのエネルギーを上げるには，それに比例して加速器が大きくなり経費す大き くなる。したがって，アンジュレーターの周期長をいかに短くするかがポイントになる.

周期長の $1 \mathrm{~mm}$ 程度, あるいはそれ以下のものをマイクロ・アンジュレーターと呼ぶが, この多く 
は, 従来型の永久磁石に溝を堀り，ピッチを狭くするあので, 現在のところ提案のみで, 実際に実用 化されている例はまだない，それは以下に述べる事情によると思われる。例えばサマリウム・コバル トの磁石で設計した場合 ${ }^{2)}$,

$$
B_{0}[\text { Tesla }]=3.34 \exp \left[-\frac{g}{\lambda_{\mathrm{u}}}\left(5.47-1.8 \frac{g}{\lambda_{\mathrm{u}}}\right)\right]
$$

の経験則がある. 強い磁場 $B_{0}$ を作るには， $\frac{g}{\lambda_{\mathrm{u}}}$ ( $g$ は磁石間のギャップ長）をいかに小さくするかに 依存する，gは電子ビームを通すスペースをとる必要から，最小值は，ほぼ決ってしまう。つまり， 電子ビーム径 $1 \mathrm{~mm} \varnothing$ とすれば，その 3 倍は正味必要と考え，さらに真空チェンバーを磁石間に通す ことを考えれば, $g=10 \mathrm{~mm}$ は必要となる .このとき $B_{0}$ として 1 Tesla を考えると,

$$
\lambda_{\mathrm{u}} \cong \frac{5.47}{\ln 3.34} g=45.2[\mathrm{~mm}] \quad \text { となる. }
$$

そこで, 真空チェンバー内に磁石列を入れたり, 磁石に溝を入れる方式で, $\lambda_{\mathrm{u}}$ を小さくする方法を考 えているが，よい方法がまだ確立してない．

さらに（2）式からわかるように， $\lambda_{\mathrm{u}}$ を小さくすると $B_{0}$ あ小さくなり，したがって $K$ が小さくな り，放射光の強度は $K^{2}$ に依存することから効率のよい光源とならなくなってしまう.

ここで提案するプラズマ・アンジュレーターは，このマイクロ・アンジュレーターを指向するあの で，上記の磁石を利用したものと比べ，数段の利点をもっているものである.

以下，第 2 章には，プラズマ・アンジュレーターの説明と作り方，そして，その磁場分布と磁気流 体力学的平衡解について述べる. 第 3 章ではプラズマ粒子の衝突の影響拉よびプラズマの安定化につ いて述べる. 第 4 章は, プラズマ・アンジュレーターの特長を従来型アンジュレーターとの比較にお いてまとめる.

\section{2. プラズマ・アンジュレーター}

前章で述べたように, 相対論的電子ビームを蛇行させるために, その進行方向と直交する力を作用 させる周期的な場を作る必要がある。

平行あるいは逆平行に流れる電流によりプラズマを作り (第 2 図), 平面上に多数の細いプラズマ柱

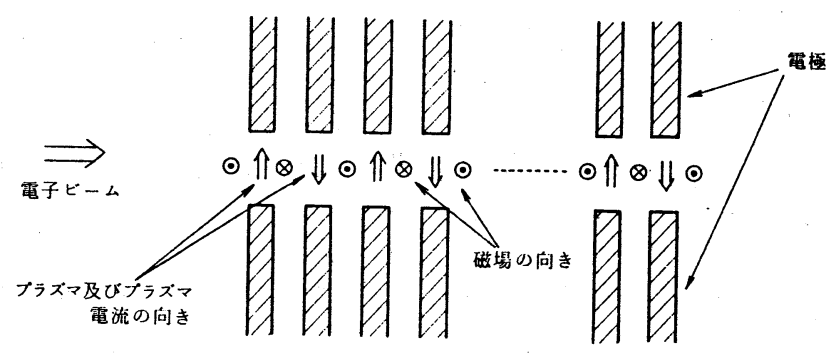

第 2 図 逆平行に電流を流すプラズマ・アンジュレーターによる周期的

磁場配位，紙面上下方向に周期的磁場が発生する. 
を並べる，その電流によって生ずる磁場分布は，その面内に垂值に，つまり電流に直交する方向にで き，相対論的電子ビームに対して，交互に向きをかえる周期的な場を与えることになる.

一方もし，このようなプラズマ柱の配列のプラズマ密度に注目すれば，それは周期的な密度分布が できていることを意昧し，これが相対論的電子ビームの空間電荷によって周期的電場分布と化し，こ れも蛇行させる場となりうる。ここでは, それらの方式を, 磁場型 (逆平行電流) プラズマ・アンジュ レーター, 磁場型 (平行電流) プラズマ・アンジュレーター, 電場型 (斜交型) プラズマ・アンジュ レーターと名付け，それぞれについて説明する.

\section{1 磁場型 (逆平行電流) プラズマ・アンジュレーター}

第 3 図のように，絶緣材のパイプに包まれた電極線を多数並べ，向い合わせに配列する. 向い合う 電極線の間に電圧をかけ電流を流す，互いに隣り合う電極間には逆方向の電流が流れるようにする. 放電が行えるように, 適度なガス圧を差動排気, パフ, あるいは電極材の蒸発によるガスなどで調節 する。

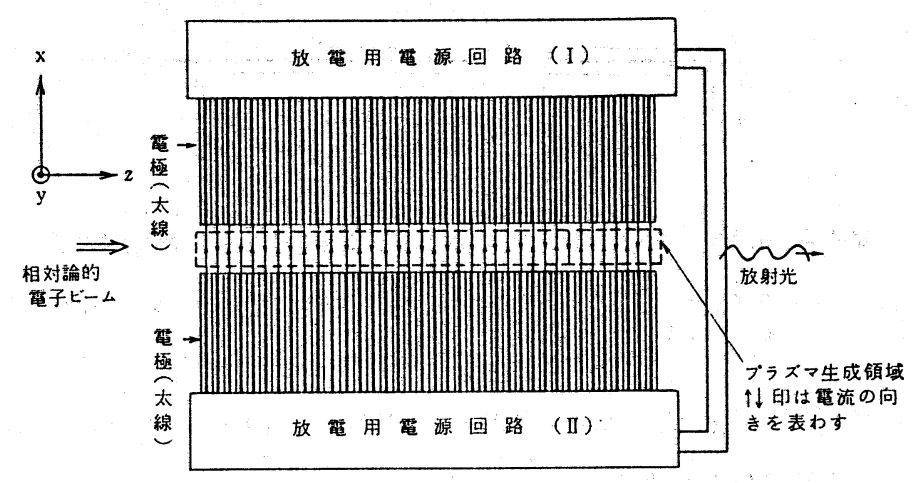

第 3 図 磁場型（逆平行電流）プラズマ・アンジュレーターの作り方. 絶縁パイプ に電極線を入れたものを多数ならへ，向い合わせた電極間に放電させる.

プラズマ中の電流により，プラズマを包むように磁場ができ，その磁場圧によりピンチ効果が発生， 細く収縮し, 系状のプラズマとなる. 図示された座標系をとると, 電子ビーム軌道 $z$ 方向に垂直な周 期的磁場分布 $B_{y}(z)$ ができる. 電子ビームの速度を $v$ とするとローレンッ力 $F=e\left(v \times B_{y}\right)$ の力を $x$ 方向に受けることになり， $x z$ 面内を蛇行することになる：その際，アンジュレーター放射光（シン クロトロン放射光）を発生させることになる.

放電させるための電気回路は, 第 4 図のように向い合う電極間にインダクタンスをつないで直列に つなぐようにし，パルス回路で電圧をかければ，電極間に電圧がかかり，放電が発生する，あし，あ る電極間に放電が起きないとすれば，パルス回路の全電圧がそこに集中的にかかり，放電することに なる.このようにすれば，各電極間に流れる電流はすべて等しくなる. 


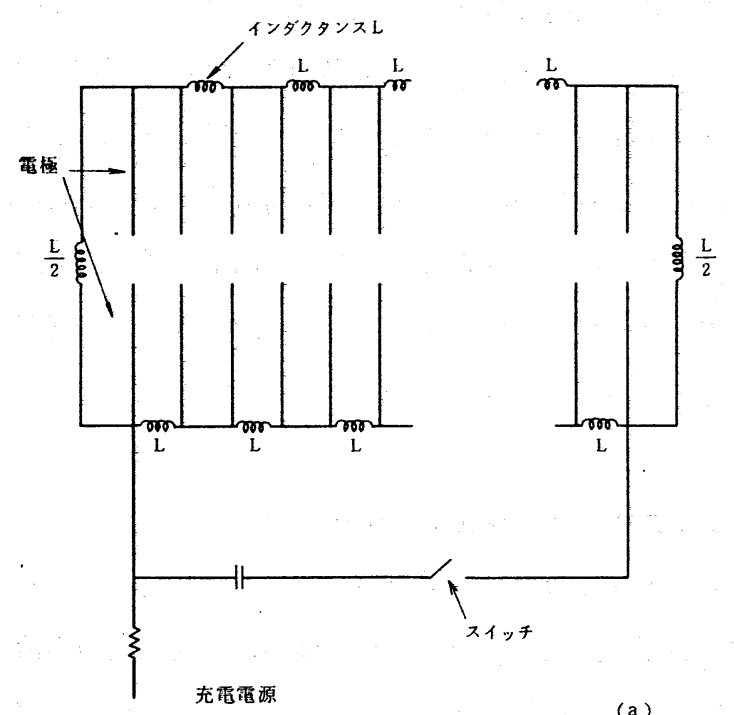

(a)

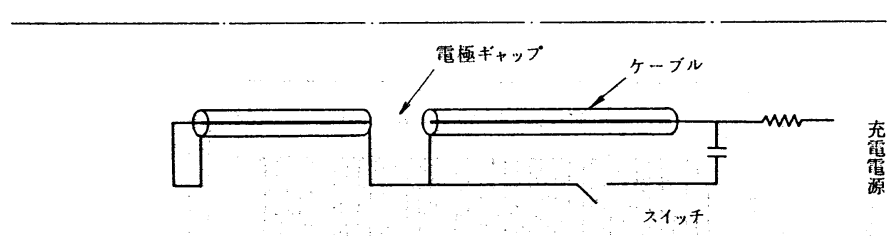

(b)

第 4 図 磁場型（逆平行電流）プラズマ・アンジュレーター用放電回路の例 (a) 直列方式，(b) 並列方式

スイッチはレーザ光あるいは電子源からの光，インダクタンスは抵 抗，コンデンサーはケーブルを代用できる.

アンジュレーターの周期は電極線 2 本で 1 周期となるから, 電極線間の距離を $d$ とすれば $\lambda_{u}=2 d$ となる. $y z$ 面 $(x=0)$ の磁場分布を考えよう.

まず，半径 $r_{0}$ のプラズマ円柱があり，その中に一様に電流が流れているとする．全電流は $I$ とす ると, プラズマ柱の中のポロイダル磁場はよく知られているように, 円筒座標 $r, \theta, \zeta$ を用いて,

$$
\begin{aligned}
B_{o} & =\frac{\mu_{0} r I}{2 \pi r_{0}^{2}} \quad\left(r \leqq r_{0}\right) \\
& =\frac{\mu_{0} I}{2 \pi r} \quad\left(r>r_{0}\right),
\end{aligned}
$$

と表されることを念頭に， $z=z_{0}, z_{0} \pm n d(n=1,2, \ldots, n)$ を中心とする半径 $d / 2$ のプラズマ柱が $2 N+1$ 本あり, 互いに隣り合うプラズマ中には逆方向の電流が流れていると考えよう：この時， $z_{0}-$ $d / 2 \leqq z \leqq z_{0}+d / 2$ の範囲で $x=0$ 面での磁場 $B_{\mathrm{y}}(z)$ は以下のように表される.

$$
\begin{aligned}
B_{\mathrm{y}}(z) & =\frac{2 \mu_{0} I}{\pi d^{2}}\left(z-z_{0}\right)+\sum_{n=1}^{N} \frac{(-1)^{n} \mu_{0} I\left(z-z_{0}\right)}{\pi\left\{\left(z-z_{0}\right)^{2}-(n d)^{2}\right\}} \\
& =\frac{2 \mu_{0} I}{\pi d^{2}}\left(z-z_{0}\right)\left\{1+\frac{1}{2} \sum_{n=1}^{N} \frac{(-1)^{n}}{\left\{\left(z-z_{0}\right) / d\right\}^{2}-n^{2}}\right\}
\end{aligned}
$$


$N \rightarrow \infty$ と近似すれば，級数の公式により，

$$
\begin{aligned}
B_{\mathrm{y}}(z) & =\frac{2 \mu_{0} I}{\pi d^{2}}\left(z-z_{0}\right)\left\{1-\frac{1}{2}\left(\frac{d^{2}}{2\left(z-z_{0}\right)^{2}}-\frac{\pi d}{2\left(z-z_{0}\right)} \times \frac{1}{\sin \pi\left(z-z_{0}\right) / d}\right)\right\} \\
& =\frac{2 \mu_{0} I}{\pi d}\left[\frac{\left(z-z_{0}\right)}{d}-\frac{d}{4\left(z-z_{0}\right)}\left\{1-\frac{\pi\left(z-z_{0}\right) / d}{\sin \pi\left(z-z_{0}\right) / d}\right\}\right] .
\end{aligned}
$$

したがって, $B_{\mathrm{y}}\left(z_{0}\right)=0, B_{\mathrm{y}}\left(z_{0}+d / 2\right)=\mu_{0} I / 2 d$ となり, プラズマ柱単独の時の最大值 $B_{\mathrm{y}}\left(z_{0}+\right.$ $d / 2)=\mu_{0} I / \pi d$ と比べると第 5 図のように $\pi / 2$ 倍大きくなる. そして, 次の周期 $z_{0}+d / 2 \leqq z \leqq z_{0}$ $+3 / 2 d$ では逆方向の勾配となり，これと合わせて 1 周期 を作る三角波になることがわかる.

ここで, 装置パラメータを想定して具体的に考えてみよ う. $d=1 \mathrm{~mm}, I=1 \mathrm{kA}$ とすると，

$$
B_{\max }=0.62[\mathrm{~T}]
$$

(2) 式より $K$ パラメータは, $K=0.12$ となる.

相対論的電子ビームとして, 現在, 原研で建設中の自由 電子レーザー用超電導加速器からのあのを想定すると, $\gamma$ $=40($ 約 $20 \mathrm{MeV})$ となり, アンジュレーター放射光の波 長 $\lambda$ は,

$$
\lambda=\frac{\lambda_{\mathrm{u}}}{2 \gamma^{2}}\left(1+\frac{K^{2}}{2}\right)=0.63 \mu \mathrm{m}
$$

となる，従来型のアンジュレーターを用いる現在の設計で は, 約 $10 \mu \mathrm{m}$ の発振を目指しているのと比べてはるかに 短波長となる。

磁気流体力学的な平衡解も次のよう計算できる. 直線 型放電で作る $z$-pinch の場合を考えて, 磁束関数を導入 する．今の場合， $x$ 方向に移動しても変らない移動対称性 (translational symmetry) の場合には, ベクトル・ポテ ンシャル $A_{\mathrm{x}}$ を用いて磁束関数を表すことができる ${ }^{3)}$. $-d / 2 \leqq z \leqq d / 2$ には一様電流が流れ， $z= \pm d$ には逆 方向に同じ量の電流が流れる場合の $A_{\mathrm{x}}$ は, 円柱座標で表

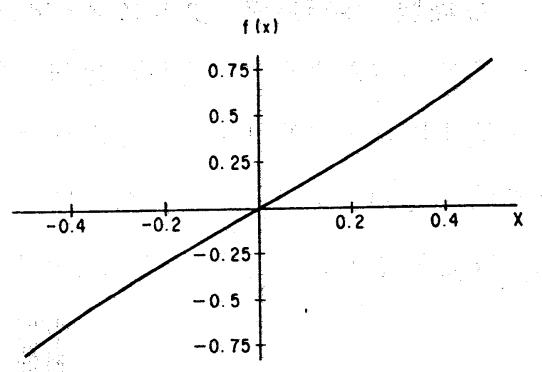

第 5 図 $X=\left(z-z_{0}\right) / d$ とおいて $f(x)=X$ $-(1 / 4 x) \cdot\{1-\pi x / \sin \pi x\}$ のグラフ. 半周期分が書かれており，あとの半周期は このグラフを鏡映したものがつづく．－周 期としては三角波となる。縦軸は単独のプ ラズマ表面での磁場の 2 倍を 1 としている. つまり約 1.6 倍の磁場強度となる.

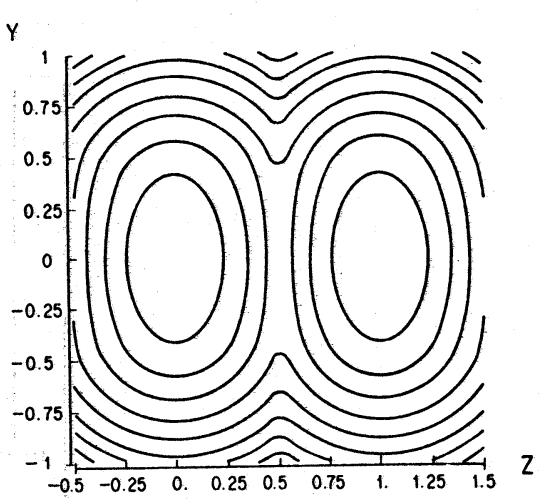

第6 図 $A_{\mathrm{x}}=\frac{\mu_{0} I}{4 \pi}\left[4\left(Y^{2}+Z^{2}\right)-\ln \left\{1+\left(Y^{2}\right.\right.\right.$ $\left.\left.\left.+\boldsymbol{Z}^{2}\right)^{2}-2\left(\boldsymbol{z}^{2}-\boldsymbol{Y}^{2}\right)\right\}\right]$ の等ポテンシャ ル面，但し， $0.5 \leqq z \leqq 1.5$ の範囲は $-0.5 \leqq z \leqq 0.5$ の図をそのまま移動し た. せば,

$$
A_{\mathrm{x}}=\frac{\mu_{0} I}{\pi} \frac{r^{2}}{d^{2}}-\frac{\mu_{0} I}{4 \pi} \ln \left(r^{4}+d^{4}-2 r^{2} d^{2} \cos 2 \theta\right)
$$

あるいは $Y=y / d, Z=z / d$ と座標変換して, 


$$
A_{\mathrm{x}}=\frac{\mu_{0} I}{4 \pi}\left[4\left(Y^{2}+Z^{2}\right)-4 \ln d-\ln \left\{1+\left(Y^{2}+Z^{2}\right)-2\left(z^{2}-Y^{2}\right)\right\}\right]
$$

となる. 第 6 図に, その等ポテンシャル面 (プラズマの等圧面)を示す. $Y=0, Z=0$ の周辺では $\sqrt{3}$ : 1 の楕円形の等ポテンシャル面となることは, その周辺で展開してみればわかる. 第 5 図からもわ かるように，プラズマの周辺ほど磁場圧が大きくなることから，プラズマ中心でプラズマ圧が大きく 周辺に行くにつれプラズマ圧が小さくなる.

\section{2 磁場型 (平行電流) プラズマ・アンジュレーター}

前節で述べたように，電極線は向い合わせに配列するのであるが，この節では，すべて同方向に電 流を流す場合を考察する．この場合は，第 7 図のように各放電ごとに回路を並列につなぎ，電流の混 合を防ぐ必要がある．この場合には，スイッチの数が多くなるので, レーザー光のような光源で, 全 部の放電を同時にトリガーする方法が考えられる.
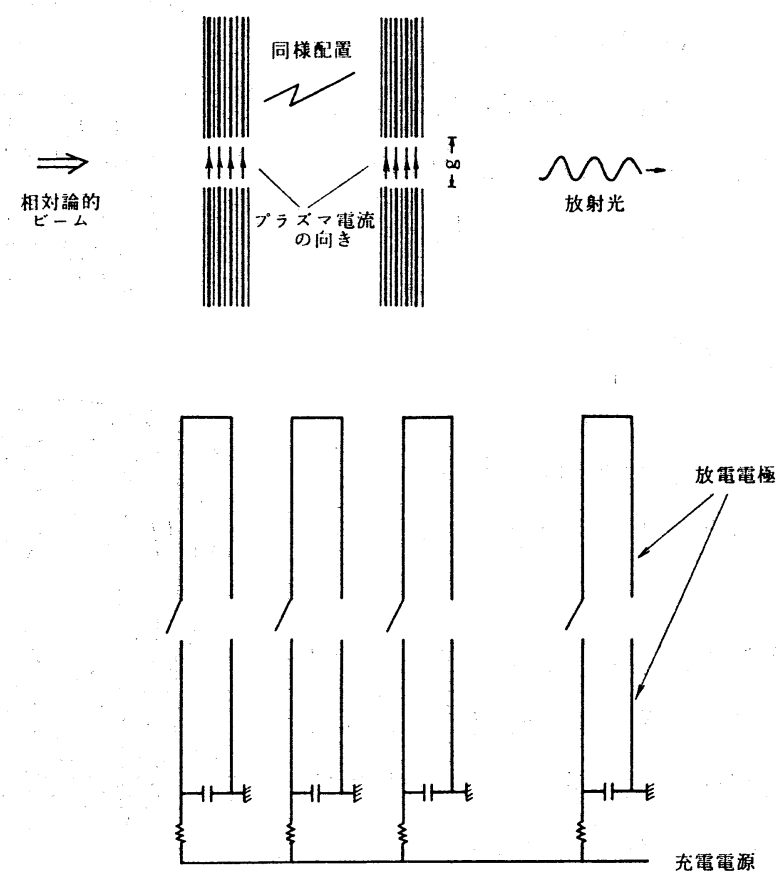

第7図 磁場型 (平行電流) プラズマ・アンジュレーターとその放電

回路. コンデンサーは，同軸ケーブルで代用も可，スイッチ は，レーザー光や加速器からの X線等を用いて同時にトリ ガーすることが可能.

磁場分布を計算すると, 前節と同じ方法により，

$$
B_{y}(z)=\frac{2 \mu_{0} I}{\pi d^{2}}\left(z-z_{0}\right)+\sum_{n=1}^{N} \frac{\mu_{0} I\left(z-z_{0}\right)}{\pi\left\{\left(z-z_{0}\right)^{2}-(n d)^{2}\right\}}
$$

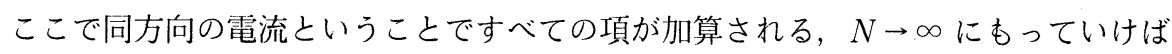




$$
\begin{aligned}
B_{\mathrm{y}}(z) & =\frac{2 \mu_{0} I}{\pi d^{2}}\left(z-z_{0}\right)\left\{1+\frac{1}{2} \sum_{\mathrm{n}=1}^{\infty} \frac{1}{\left\{\left(z-z_{0}\right) / d\right\}^{2}-n^{2}}\right\} \\
& =\frac{2 \mu_{0} I}{\pi d}\left\{X+\frac{1}{4 X}(\pi \cot \pi X-1)\right\}
\end{aligned}
$$

となり，第 8 図に示すようなグラフとなる，この場合は磁 場の周期長は $\lambda_{\mathrm{u}}=d$ となり，短波長にはなるが磁場強度 はかなり弱くなる.

さらに，前節と同じょうに，等ポテンシャル面を求めれ ば,

$$
\begin{aligned}
A_{\mathrm{x}} & =\frac{\mu_{0} I}{4 \pi}\left[4\left(Y^{2}+Z^{2}\right)-4 \ln d\right. \\
& \left.+\ln \left\{1+\left(Y^{2}+z^{2}\right)^{2}-2\left(z^{2}-Y^{2}\right)\right\}\right]
\end{aligned}
$$

から第 9 図が得られる。この場合は，プラズマの中心部之 セパラトリックスの周辺で磁場圧が 0 となり，その中間の 最大磁場圧も第 8 図に見られるように小さいことから，む しろ，プラズマ中に電流チャンネルが埋没してとイメージ した方が妥当で，大きな $B_{\max }$ は得にくいことがわかる.

\section{3 電場型 (斜交型) プラズマ・アンジュレーター}

プラズマ中の電流によってアンジュレーターを作るのに 対して，細いプラズマ間に生じる電場によってアンジュレー 夕ーを作ることもできる，ただし，電子ビームと直交する 方向に周期的電場を作るためには, 第 10 図のように, 細 いプラズマを斜めに作る必要がある，プラズマ密度が周期 的に分布しているところに，相対論的電子ビームが入って くると, 質量の重い相対論的電子ビームの電荷 によってプラズマ電子が押しのけられ，結果的 にイオンのリップルの電場の中を通ることにな る.この電場は斜交することにより，電子ビー ムと直交する電場成分をむつことになる。つま り,この場合にも, $y=0$ 平面上に蛇行するこ とになる゙．

第 10 図の $(Z, X)$ 座標で考える.イオンの密 度は $n_{\mathrm{i}}=n_{0}\left[1+\delta_{\mathrm{i}} \sin k Z\right), k=2 \pi / d$ すると，

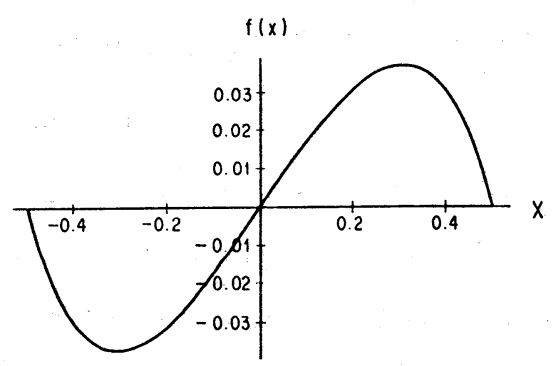

第 8 図 $X=\left(z-z_{0}\right) / d$ とおいて, $\boldsymbol{f}(\boldsymbol{X})=X$ $+(1 / 4 X)\{\pi \cot \pi X-1\}$ のグラフ, 縦軸は単独プラズマ表面の磁場の 2 倍を 1 としている．つまり，6\%の磁場強度とな る.

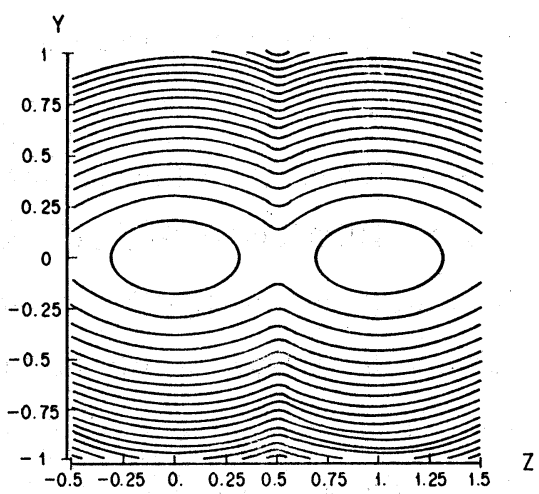

第 9 図 磁場型 (平行電流) プラズマ・アンジュレー ターの平衡解， $A_{\mathrm{x}}=\frac{\mu_{0} I}{4 \pi}\left[4\left(X^{2}+Y^{2}\right)\right.$ $\left.+\ln \left\{1+\left(Y^{2}+z^{2}\right)^{2}-2\left(z^{2}-Y^{2}\right)\right\}\right]$ 等 ポテンシャル面. 但し $0 \leqq z \leqq 1.5$ の範 囲は， $-0.5 \leqq z \leqq 0.5$ の図をそのまま移 動した.

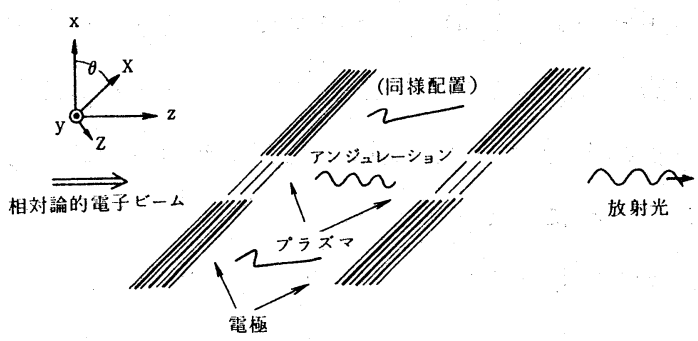

第 10 図 電場型プラズマ・アンジュレーター. プラズマの密度 変化と相対論的電子ビームの空間電荷との相互作用で イオン・リップルを作り斜交させることによってアン ジュレーター作用を作る. 


$$
\operatorname{div} \mathbf{E}=e n_{0} \delta_{\mathrm{i}} \sin k Z / \varepsilon_{0}, \quad\left(\varepsilon_{0} \text { は誘電率 }\right)
$$

から

$$
\mathbf{E}=-e n_{0} \delta_{\mathrm{i}} \cos k Z / k \varepsilon_{0} \cdot \hat{Z}
$$

となる.ここで $\hat{Z}$ は $Z$ 方向の単位べクトルである.つまり，相対論的電子ビームと直交する成分は

$$
E_{\mathrm{x}}=+e n_{0} \delta_{\mathrm{i}} \cos k_{\mathrm{u}} z \cdot \sin \theta / k \varepsilon_{0}=e n_{0} \delta \cos k_{\mathrm{u}} z \cdot \sin \theta / k_{\mathrm{u}} \varepsilon_{0}
$$

ここで, $\delta=\delta_{\mathrm{i}} \cos \theta, k_{\mathrm{u}}=k \cos \theta$ とする.

もし, 電子ビーム密度 $\left(n_{\mathrm{b}}\right)$ がプラズマ密度以上の場合には, プラズマ中の軽い電子は電子ビーム軌 道からとばされ， $n_{0} \delta_{\mathrm{i}} \sin k Z$ のイオンリップル中を電子ビームが運動することになる.

$n_{\mathrm{b}}$ として $10^{8} \mathrm{~A} / \mathrm{m}^{2}$ の相対論的電子ビームを考えると $n_{\mathrm{b}} \cong 2 \times 10^{20} / \mathrm{m}^{3}$ となる. $n_{0}=n_{\mathrm{b}}, \delta=0.01$, $k=2 \pi \cdot 10^{+3}, \theta=\pi / 4$ とすると $E_{\mathrm{x}} \approx 400 \mathrm{MV} / \mathrm{m}$ となる: ローレンッ力, $F=e\{E+C \times B\}$ の磁場 $B$ と比較して, この $E_{\mathrm{x}}$ は $1.3 \mathrm{~T}$ の磁場に相当することがわかる. 文献 4）によると, 超音波+レーザ 光, あるいは, Ion accoustic 波によるイオン・リップルを提案しているが, このプラズマ・アンジュ レーターはより短いピッチのアンジュレーターを作るために直接放電によってイオン・リップルを作 るあのである.

斜交の角 $\theta$ を $\pi / 4$ とすると, このアンジュレーターの周期長は $\lambda_{\mathrm{u}}=\sqrt{2} d$ となる.

なお，放電の作り方に関しては，文献 7）に詳しく，放電開始電圧は，ガス，陰極材料によって異な るが, pg (Torr $\cdot \mathrm{cm})$ の関数として示され (パッシェン曲線), 約 $1 \sim 10(\mathrm{Torr} \cdot \mathrm{cm})$ で, 最小值 $300 \mathrm{~V}$ 前後である。陰極降下電圧は $10 \mathrm{~V}$ 程度であるから，放電維持電圧はこれ以上あればよい，また，プ ラズマ電流の密度も，陰極の近くで銅と銅の放電で $10^{6} \mathrm{~A} / \mathrm{cm}^{2}\left(10 \mathrm{kA} / \mathrm{mm}^{2}\right)$ から炭素と炭素の 500 $\mathrm{A} / \mathrm{cm}^{2}$ まで種々のデータがあり，実験的な方法で選択すべきであろう.

\section{3. プラズマ粒子の衝突の影響とプラズマの安定化}

プラズマ・アンジュレーターを議論する時, あっとも気になるのは, プラズマ粒子による衝突の影 響である．上くに，リング加速器*は，リング中の真空度を極端によくするように腐心しているのに， 電子ビームの軌道上にプラズマを作るとはもっての外と考えられるがす知れない，しかし，リング加 速器の場合には, 眝蔵された電子ビームを長時間リング内を周回させるものであり, ある個所で衝突 の影響を受ければ，周回のたびに軌道への影響を加算されるのである．このような心配は，リニアッ クのように, ビームを 1 回のみアンジュレーターに通す場合には要らない。 むしろ, 線型加速器側の 真空度, 電子銃のあたりの真空度に影響のないように配慮すればよいことになる.

さて, 衝突の影響としては, プラズマを構成するイオンと電子による相対論的電子ビームの損失（散

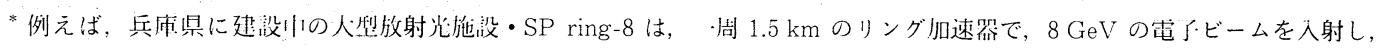

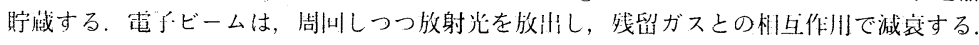


乱)，エネルギー損失 (制動輻射)，エミッタンス变化等が考えられる.

散乱断面積の式を列挙すると以下のようになる

$$
\sigma_{\mathrm{R}}(z)=\frac{4 \pi z^{2} r_{\mathrm{e}}^{2}}{\gamma^{2} \theta^{2}}
$$

(13) Rutherford 散乱の公式

であり，原子核（原子番号 $\mathrm{z}$ ）の反跳を無視した場合で散乱角 $\theta$ 以上の全断面積である． $r_{\mathrm{e}}$ は古典電 子半径 $\left(2.818 \times 10^{-15} \mathrm{~m}\right)$ である.

$$
\sigma_{\mathrm{M}}=\frac{4 \pi r_{\mathrm{e}}^{2}}{\gamma^{2} \theta^{2}} \quad \text { (14) M } \quad \text { pller 散乱の公式 }
$$

であり，核外電子とクーロン散乱をして， $\theta$ 以上の角度で失われる全断面積である. Rutherford 散乱 の $z=1$ とした場合に等しい.

$$
\sigma_{\mathrm{B}}(z)=\frac{4 r_{\mathrm{e}}^{2}}{137} z(z+1) \cdot \ln \left(183 / z^{1 / 3}\right) \cdot\left[+\frac{4}{3} \ln \frac{\gamma}{\gamma_{\mathrm{c}}}-\frac{5}{6}\right]
$$

これは電子ビームのエネルギーが $\gamma$ から $\gamma_{\mathrm{c}}$ だけ損失するまでの全断面積である． $\gamma_{\mathrm{c}}$ は加速器研究分 野では, RF バケットから飛び出すエネルギーロスからきめられるあのであるが, 自由電子レーザー の場合には，入射電子ビームのエネルギー幅 $(1 / 2 N)$ との関係を考慮する必要がある．（Nはアンジュ レーターのピッチ数)

一般に,これらの散乱によって失われる電子ビームの寿命は $\frac{1}{\tau}=-\frac{1}{n} \frac{\mathrm{d} n}{\mathrm{~d} t}$ で定義され，上記の $\sigma_{\mathrm{R}, \mathrm{M}, \mathrm{B}}$ を用いて

$$
\begin{aligned}
& \frac{1}{\tau_{\mathrm{R}}}=C N_{\mathrm{P}} \sigma_{\mathrm{R}}, \\
& \frac{1}{\tau_{\mathrm{M}}}=C N_{\mathrm{P}} z \sigma_{\mathrm{M}}, \\
& \frac{1}{\tau_{\mathrm{B}}}=C N_{\mathrm{P}} \sigma_{\mathrm{B}},
\end{aligned}
$$

と表される.これら全ての散乱によるビーム損失は

$$
\frac{1}{\tau_{\mathrm{G}}}=\frac{1}{\tau_{\mathrm{R}}}+\frac{1}{R_{\mathrm{M}}}+\frac{1}{\tau_{\mathrm{B}}}
$$

であり, $\frac{\Delta n}{n}=\frac{\Delta t}{\tau_{\mathrm{G}}}, \Delta t=\frac{\ell}{c}$ として,

$$
\frac{\Delta n}{n}=\ell N_{\mathrm{P}}\left\{\sigma_{\mathrm{R}}+z \sigma_{\mathrm{M}}+\sigma_{\mathrm{B}}\right\}
$$

と考えてよい.ここで $N_{\mathrm{P}}\left[\mathrm{m}^{-3}\right]=3.22 \times 10^{22} \mathrm{P}[\mathrm{Torr}]$ であり, $\ell$ はプラズマ・アンジュレーターの長 さとする.

例えば, $z=7, \gamma=40(\sim 20 \mathrm{MeV}), N_{\mathrm{P}}=1 \mathrm{Torr}, \quad \ell=1 \mathrm{~m}, \theta=g / 2 \ell=5 / 2000 \quad(g$ は電極間の距 離）の場合を考えると， $\sigma_{\mathrm{R}}$ の寄与が一番大きくなって

$$
\Delta n / n=3.22 \times 10^{22} \times 4.8 \times 10^{-25} \sim 1.5 \times 10^{-2}
$$

1 Torr の窒素ガスを用いてもこの程度である: プラズマ・アンジュレーターの場合には散乱の影響は 
無視できることになる.

一般にエミッタンス $(\varepsilon)$ の増加量は, 電子ビームのベータ関数を $\beta$, ディスパージョンは無いもの と仮定すると, 1 回の衝突あたりの变化分 $\Delta \varepsilon$ は $^{6)}$,

$$
\Delta \varepsilon=\frac{\beta}{2}<\theta^{2}>\quad(\theta \text { は散乱角, }<>\text { は平均を表す })
$$

と表される.すなわち長さ $\ell$ のプラズマ・アンジュレーターを通過する間に変化するエミッタンスは,

$$
\Delta \varepsilon=\frac{\ell}{c} \cdot c N_{\mathrm{P}} \frac{\beta}{2} \sigma<\theta^{2}>=\frac{\ell N_{\mathrm{P}}}{2} \sigma<\theta^{2}>\cdot \beta
$$

弾性散乱による $\sigma<\theta^{2}>$ は散乱角の最大は原子核程度による電子波の回折角, 最小は原子半径程 度による回折角と見積られて，

$$
\sigma<\theta^{2}>=\frac{8 \pi r_{\mathrm{e}}^{2} z^{2}}{\gamma^{2}} \ln \frac{4.1 \times 10^{4}}{(A z)^{1 / 3}}
$$

また制動放射の場合を考えても，

$$
\sigma<\theta^{2}>=\frac{2 r_{\mathrm{e}}^{2}}{137} z(z+1)\left[\frac{8}{3} \ln \frac{183}{z^{1 / 3}}+\frac{2}{9}\right] \frac{\ln \gamma}{\gamma^{2}}
$$

と表される.

$\beta$ 関数はプランナー型のアンジュレーターの場合には, Halbach ${ }^{2)}$ れているから, 前章で考えたようなパラメータをとり, $\lambda_{\mathrm{u}}=\frac{2}{1000}[\mathrm{~m}], K=0.1$ とすると $\beta=0.18 \mathrm{~m}$ となり,

$$
\Delta \varepsilon \cong 1 \times 10^{-8} \quad[\mathrm{~m} \mathrm{rad}]
$$

程度となる.これは常温ガス 1 Torr の圧力で, $20 \mathrm{MeV}$ の場合でさえ，この程度であることを考える と，このプラズマによるエミッタンスの増加も非常に小さいむのと考えてよいことがわかる．ちなみ に, 現在原研で建設中の超電導加速器リニアックの設計ではエミッタンスは $10^{-5}$ 代を目標としている.

安定な放電の形成, プラズマの安定化について検討する. まず, 放電の形成で気になるのは, 所定 の電極間で放電が起き, それが持続できるかである. 対向する電極間ではなく, 隣りの電極間で放電 することは十分考えられる. また, 特に磁場型プラズマ・アンジュレーターの場合にプラズマ柱同志 の反挑力あるいは吸引力をどのように抑えるかが問題点となる.

さらに, 磁場型のように, 大きな電流を流して強い磁場を作りたい場合には, プラズマ柱自身の電 磁流体力学的不安定性, 例えば, ソーセージ不安定性, キンク不安定性と呼ばれる不安定性などにつ いては安定化の方策を考えておく必要がある ${ }^{3)}$.

これらの問題を解決する特効薬は，いわゆる縦磁場を使うことである. 電流と同じ方向に磁場を作 ることによってプラズマを安定化する方法はよく知られていることであるが，これは, 磁場は磁力線 を包む面には $B^{2} / 2 \mu_{0}$ の圧力をむち，また磁力線の方向には $B^{2} / 2 \mu_{0}$ の張力をむつ性質によるもの 
である。

縦磁場が放電形成時に，対向する電極間に放電しやすく するのは論をまたないし，たとえ隣りの電極間で放電して 屯，すぐに対向電極と放電が移行するであろう．プラズマ 柱同志の反挑力あるいは吸引力に対しても, 磁力線の張力 が一定の効力がある筈である.

ソーセージ不安定性とキンク不安定性は第 11 図に示し たたような磁気流体力学的不安定性であるが，その安定化 条件は，よく知られているように，プラズマ電流 $I_{x}$ によ るポロイダル磁場 $B_{\theta}$ として, 半径 $d / 2$ のプラズマに対

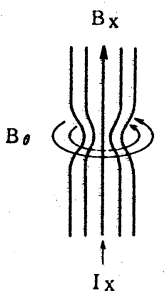
ソーセージ不努定姓

第 11 図 ソーセージ不安定性とキンク不 安定性. 磁気流体力学的不安定 性の基本的なもの二つ

して

$$
B_{x}^{2}>\frac{B_{\theta}^{2}}{2}=\frac{1\left(\mu_{0} I_{x}\right)^{2}}{2(\pi d)^{2}} \quad(\text { ソーセージ不安定性), }
$$

つまり，

$$
B_{x}>\mu_{0} I_{x} / \sqrt{2} \pi d
$$

キンク不安定性については,

$$
B_{x}>\frac{g B_{\theta}}{\pi d}=\frac{g \mu_{0} I_{x}}{(\pi d)^{2}} \quad \text { (キンク不安定性) }
$$

で表され， $B_{x}$ を作ることが安定化の条件となる。これはクルスカル・シャフラノフの条件と㭔ばれる. ここで, $g$ は電極間のギャップ長，つまり，プラズマの長さである，一般に $g / \pi d>1$ であろうから， クルスカル・シャフラノフの条件を満たす縦磁場 $B_{x}$ の方を考えれば両方を安定化できるであろう.

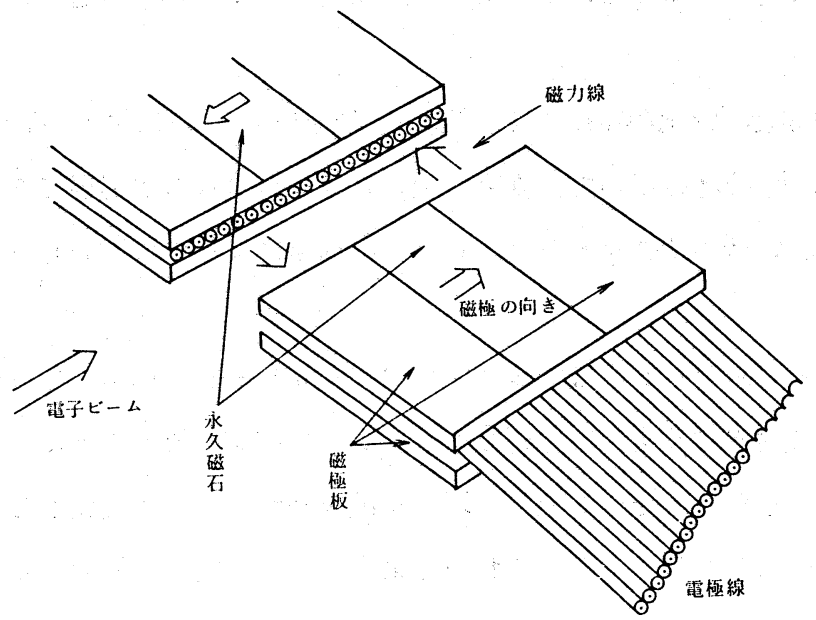

第 12 図 プラズマ安定化の一方法（縦磁場方式）。同一の磁極板・永久磁石 磁石で電極線をサンドイッチにはさみ，それを向い合せにする. 磁 力線のかからぬ電極線は省略するか，放電しないようにすればよい， 
この縦磁場 $B_{x}$ は, 相対論的電子ビームそのものを大きく偏向させてしまう可能性がある. ただし この場合は, プラズマ電流による磁場 $B_{y}$ によるものは, $x$ 方向にアンジュレーション運動するのに 対して， $B_{x}$ はそれと直交する方向つまり $y$ 方向に偏向する．この電子ビームの偏向を直すためには， 向きが逆の磁場 $-B_{x}$ を電子ビーム軌道上に置き, 矯正すればよい，つまり，第 12 図のように，永久 磁石を電極をはさむように配置して，ピッチの長いアンジュレーター磁場を作机ばよ。アンジュレー ション運動が直交すること, ピッチ長が大きく異なること から，2つの波長の光が放出されるとしても，相互に大き な影響を及ぼさないであろう。ただし，アンジュレーショ ン軌道の波長を $\lambda_{\mathrm{s}}$ として, その振幅 $K \lambda_{\mathrm{s}} / 2 \pi \gamma$ がプラズ マ半径から大きくはみ出さないことが必要である.

細いプラズマ中の電流が隣り同志逆方向に流れる時, 互 いに反挑力が働く.このため, プラズマ列の端にアンカー コイルと名付けるループを作り, これに同じ電流を流して 反挑力を抑える方法がある。第 13 図のように垂㨁磁場を 作る方法である.

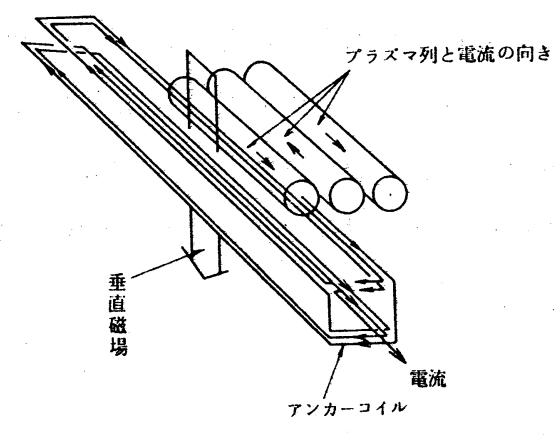

第 13 図 アンカーコイル. プラズマ柱列の反撥が強い時，垂直 磁場で抑えるためのコイル.

\section{4. プラズマ・アンジュレーターの特徴・まとめ}

前章までの検討をふまえて，プラズマ・アンジュレーターの特徴を以下のようにまとめてみる.

（1）従来の永久磁石のマイクロポール・アンジュレーターと比べて $g / \lambda_{\mathrm{u}}$ を大きくとれる.これは 遠方の電極によって放電させることによって, 相対論的電子ビームの軌道上に周期的磁場を直接作る ことができることによる.

（2）したがって，生成される磁場あるいは電場は十分強いものが期待できる.

（3）細い電極, 薄い絶縁材を用いて, 極めて短いピッチ長のものが実現でき, また最近開発されて いる半導体技術, あるいはマイクロ・テクノロジーの利用により更に短いピッチ長のあのが期待でき る.

（4）プラズマ・アンジュレーターはパルス的にアンジュレーター作用を作り出せることも大きな特 長であり, 普段は, 放電させずにおき, 必要なタイミングで電流を流すことによってアンジュレーター とすることができる.しかも，その電流（磁場）を電気回路によって变化させることにより，発生す る光の波長を変化させることができる．これを従来型が, 機械的に磁極のキャップ間隔を変える方式 と比べて格段の利点である.

（5）前章までは, 電子ビームの加速器として線型加速器を想定したが，これは真空度の悪さがビー ム寿命に影響するからである。しかし，アーク放電のように電極材の蒸発やパフのように一時的にガ 
スを注入する方式を工夫すれば，真空度の悪い部分は局所化することができ，またパルス的にするこ とができる。このような場合にはストレージ・リング型にも，プラズマ・アンジュレーターは適用で きる.ビーム入射時には, アンジュレーション作用を起こさせなかったり，ビームのエミッタンスが よくなるためのダンピング時間をリング自身に与え，パルス的にアンジュレーター作用を作る方式を とれば,リング軌道上にバイパスをわざわざ作らなくてむよくなる。

(6) アンジュレーション運動の面が, 電極の置かれる平面上であり, 従来型の磁極へ置かれる面と 直交するのと異なる点も留意する必要がある.

（7）プラズマ中を電子ビームを通すことによって，電子ビームを収束させることができる（プラズ マ・レンズ作用)：これは，放射する光を増幅させる効果をあたらすであろう.

（8）また，プラズマ中では電磁波（光）に対する屈折率が小さくなることから，電磁波を光軸上に 収束する作用すある（オプティカル・ガイド作用）。この作用を利用すれば，高効率自由電子レーザー が得られる.

（9）最大の問題は，磁場分布の制御は非常に難しく，基本波だけのアンジュレーター磁場とはなら ないであろう。したがって高調波の発生は覚悟しなくてはならない.これらは実験によって定められ るであろう.

最後に, アンジュレーター放射光の全放射パワーと自由電子レーザーのピーク増幅率 Gをアンジュ レーターの長さ $\ell=0.4 \mathrm{~m}(N=200)$ の場合についてあたってみよう.

全放射パワーは ${ }^{1)}$

$$
P_{\mathrm{T}}=1.65 \times 10^{-4} \gamma^{2} B_{0}^{2} \ell(\mathrm{m}) \bar{I}(\mathrm{~A}) \quad[\text { 〔ワト }
$$

今 $B_{0}=0.62[\mathrm{~T}], \bar{I}=100 \mathrm{~A}, \gamma=40$ として

$$
P_{\mathrm{T}}=4 \quad \text { ワット となる }
$$

また，ピーク増幅率は，電子パルスを光の断面積と等しいとし，それを $\Sigma_{\mathrm{e}}$ と表すと，

$$
\mathrm{G}=2^{5 / 2} \pi^{2} \lambda_{\mu}^{1 / 2} \lambda^{3 / 2} N^{3} \frac{K^{2}}{\left(1+K^{2}\right)^{3 / 2}} \frac{\bar{I}}{I_{\mathrm{A}} \Sigma_{\mathrm{e}}} \mathrm{F}(K) \mathrm{C}(x)
$$

となる, $I_{\mathrm{A}}=4 \pi \varepsilon_{0} \mathrm{me}^{3} / \mathrm{e}=1.7 \times 10^{4} \mathrm{~A}$ (Alfvén current) であり

$$
\begin{gathered}
\mathrm{F}(K)=\left[J_{0}\left\{\frac{K_{2}}{2\left(1+K^{2}\right)}\right\}-J_{1}\left\{\frac{K_{2}}{2\left(1+K^{2}\right)}\right\}\right]^{2} \\
\mathrm{C}(x)=-\frac{\mathrm{d}}{\mathrm{d}_{x}}\left(\frac{\sin x}{x}\right)^{2}
\end{gathered}
$$

ここで $\mathrm{C}(x)$ は $x=5 / 4$ のとき最大值 0.54 をとる.

$$
\begin{aligned}
& K=0.12, \Sigma_{\mathrm{e}}=(0.5)^{2} \pi \times 10^{-6} \mathrm{~m}^{2} \text { とおけば } \\
& \mathrm{G} \fallingdotseq 5.6 \times 10^{-3} \bar{I}
\end{aligned}
$$

となり, $\bar{I}=2 \mathrm{~A}$ であれば, 光共振器の損失が $1 \%$ あっても発振できることになる. また $\ell=2 \mathrm{~m}$ に 
するか，あるいは $\bar{I}=200 \mathrm{~A}$ あれば，G>1になり，いわゆる SASE (Self Amplified Spontaneous Enission) の検討領域に入り， ワンパスで高増幅率で発振する可能性を示す.

\section{謝 辞}

本論文を作成するにあたって，日本原子力研究所物理部自由電子レーザー研究室，大型放射光施設 計画推進室の諸氏の協力を得た。ここに感謝の意を表します.

\section{文献}

1）高良和武監修：シンクロトロン放射利用技術，\{(森)サイエンスフォーラム $\}$ 第 2 章 第 3 節 挿入光源, 第 4 節 自由電子レーザー。

2) K. Halbach: J. Phys. (Paris) CI 44 (1983) 211.

3）宮本健郎：核融合のためのプラズマ物理（苝波書店）1987.

4) K.R. Chen and J.M. Dawson: Physical Review Letters 68 (1992) 29.

5) 中村典雄: ビーム寿命, OHO '91 加速器セミナー (高エネルギー加速器科学奨版会).

6) 金沢健一：エミッタンスと真空度, OHO ’91 加速器セミナー (高エネルギー加速器科学奨励会).

7) A. von Engel, 山本賢三, 奥田孝美共訳, 電離気体 (コロナ社), 1957. 